\title{
Assessment of Fission Product Content of High-level Liquid Waste Supernate on E-Area Vault Package Criteria (U)
}

by

D. F. Brown

Westinghouse Savannah River Company

Savannah River Site

Aiken, South Carolina 29808

DOE Contract No. DE-AC09-89SR18035

This paper was prepared in connection with work done under the above contract number with the U. S. Department of Energy. By acceptance of this paper, the publisher and/or recipient acknowledges the U. S. Government's right to retain a nonexclusive, royalty-free license in and to any copyright covering this paper, along with the right to reproduce and to authorize others to reproduce all or part of the copyrighted paper. 


\section{DISCLAIMER}

This report was prepared as an account of work sponsored by an agency of the United States Government. Neither the United States Government nor any agency thereof, nor any of their employees, makes any warranty, express or implied, or assumes any legal liability or responsibility for the accuracy, completeness, or usefulness of any information. apparatus, product, or process disclosed, or represents that its use would not infringe privately owned rights. Reference herein to any specific commercial product, process, or service by trade name. trademark. manufacturer, or otherwise does not necessarily constitute or imply its endorsement, recommendation, or favoring by the United States Government or any ageacy thereof. The views, and opiaions of authors expressed herein do not necessarily state or reflect those of the United States Government or any agency ihereof.

This report has been reproduced directly from the best available copy.

Available to DOE and DOE contractors from the Office of Scientific and Technical Laformation. P. O. Box 62. Oak Ridge. TN 37831; prices available from (615) $576-8401$.

Available to the public from the National Technical Information Service. U. S. Departmeat of Commerce, 5285 Port Royal Rd., Springfield. VA 22161 


\section{DISCLAIMER}

Portions of this document may be illegible in electronic image products. Images are produced from the best available original document. 
WESTINGHOUSE SAVANNAH RIVER COMPANY HIGH LEVEL WASTE ENGINEERING

HIGH LEVEL WASTE ENGINEERING SUPPORT

ASSESSMENT OF FISSION PRODUCT CONTENT OF HIGH LEVEL LIQUID WASTE SUPERNATE ON E-AREA VAULT PACKAGE CRITERIA (U)

by

D. F. Brown

ISSUED: June 30, 1994

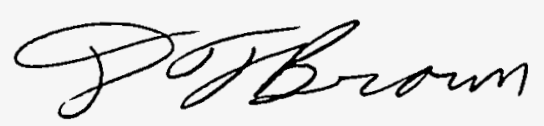

D. F. Brown, Author, HLWE

Paul D.d'entieman

P. D. d'Entremont, Technical Reviewer, HLWE
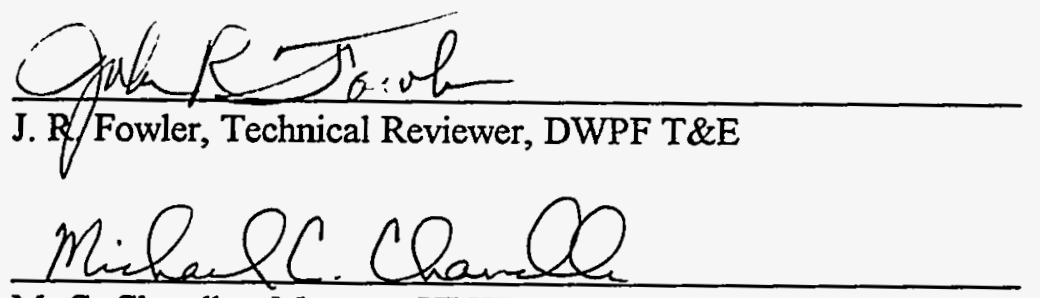

M. C. Chandler, Manager HLWE Waste Characterization

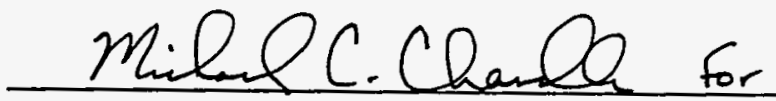

J. E. Mara, Manager HLWE Support

UUNickent fa

T. M. Monahon, Manager HWE (Approved)
WSRC-TR-94-0292

REVISION: 0

KEYWORDS:

Waste Characterization

RETENTION:

Permanent

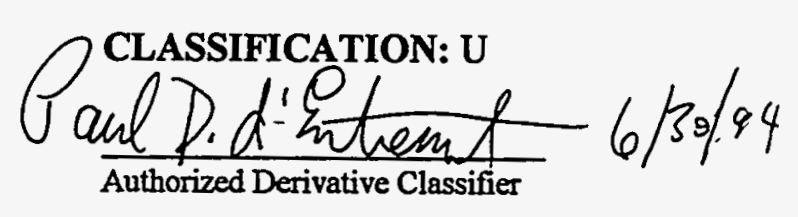

Date: $6 / 30 / 94$

Date: $6 / 30 / 94$

Date: $6 / 30 / 94$

Date: $7 / 6 / 94$

Date: $7 / 14 / 94$

Date: $7 / 14 / 94$ 
WSRC-TR-94-0292

Rev. $0(6 / 30 / 94)$

Page 2 of 17

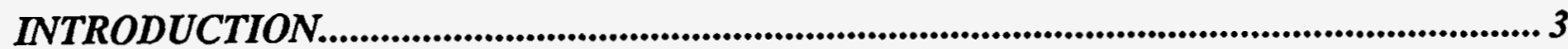

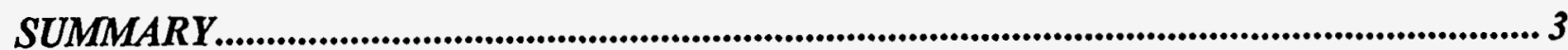

DISCUSSION .................................................................................................................................. 3

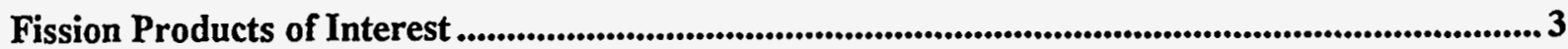

Fission Products Formed in SRS Reactor Assemblies.............................................................. 4

Reactor Assembly Fission Yield Isotope Distribution ................................................................. 4

Alternative Fission Yield Isotope Distribution ........................................................................6

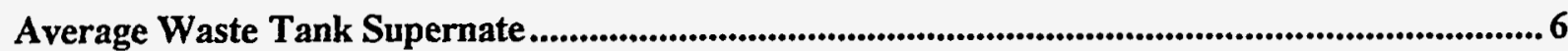

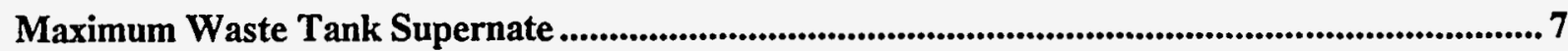

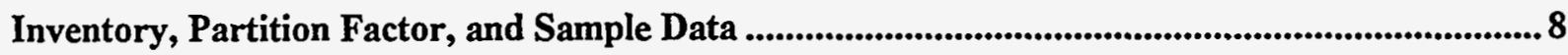

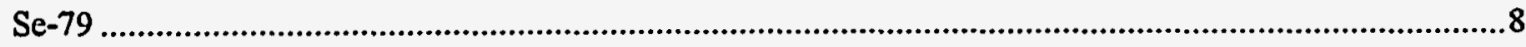

Sr-90

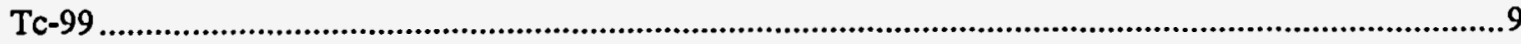

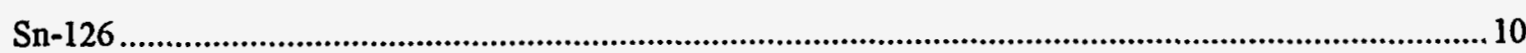

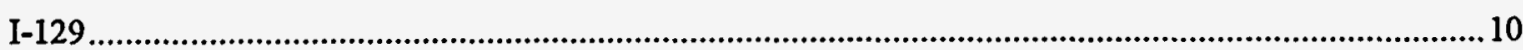

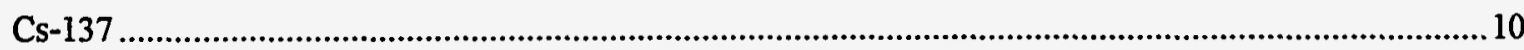

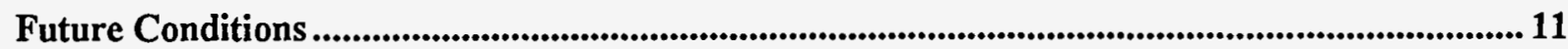

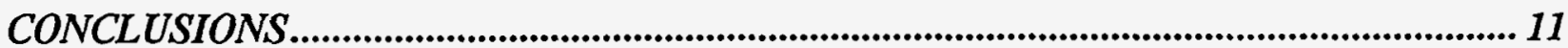

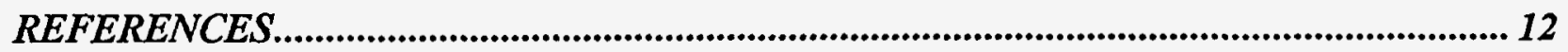

\section{ATTACHMENTS:}

Table 1 -- Fission Product Yields in Various Types of Assemblies........................................... 13

Table 2 _- Recent Supernate Characterization Samples ......................................................... 14

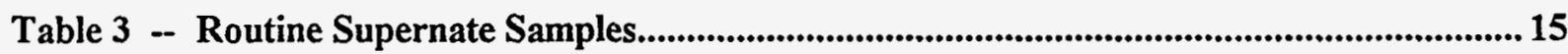

Table 4 -- Miscellaneous Supernate Samples.......................................................................................16

Chart 1 -- Cs-137 in Routine Supernate Samples.......................................................................17 
WSRC-TR-94-0292

Rev. 0 (6/30/94)

Page 3 of 17

\section{INTRODUCTION}

This report assesses the tank farm's high level waste supernate to determine any potential impacts on waste certification for the E-Area vaults (EAV). The Waste Acceptance Criteria procedure (i.e., WAC 3.10 of the $1 \mathrm{~S}$ manual) ${ }^{3}$ imposes administrative controls on radioactive material in waste packages sent to the EAV, specifically on six fission products. Waste tank supernates contain various fission products, so any waste package containing material contaminated with supernate will contain these radioactive isotopes.

This report develops the process knowledge basis for characterizing the supernate composition for these isotopes, so that appropriate controls can be implemented to ensure that the EAV WAC is met.

\section{SUMMARY}

The characterization of fission products in High Level Waste supernate is based on process knowledge of reactor fission yield, the subsequent impacts of process chemistry, and the available sample data.

Both the fission yield calculations and the available sample data confirm that Se-79, Sr-90, and Sn-126 in supernate contaminated waste will be quite minor relative to the Package Administrative Criteria, so these isotopes will not need to be listed on the waste package manifests. The waste package manifests will have to list Tc-99, I-129 and Cs-137. The "supernate contaminated" waste packages will be limited by their I129 content, so the package's Cs-137 content (i.e., their allowable dose rate) will have to be reduced $\sim 20 \%$.

The composition of waste streams related to In-Tank Processing will be documented separately. Both the In-Tank Precipitation (ITP) and Extended Sludge Processing (ESP) operations result in process streams where the Cs-137 has been concentrated or removed. Additionally, batches of spent washwater from the ESP operation will have a declining Cs-137 content, while other radionuclides could potentially maintain their original concentrations (i.e., the $\mathrm{Cs}-137$ will be diluted as the sludge washing proceeds, while other isotopes which were partially insoluble could re-dissolve from the sludge). Thus these process streams, and potentially their associated solid waste streams, will have different isotopic ratios than the tank farm's historical supernate (i.e., which results from waste receipt and concentration/evaporation operations).

\section{DISCUSSION}

\section{Fission Products of Interest}

In a nuclear reactor, a wide distribution of "fission product" (FP) isotopes results from fission of the uranium and plutonium atoms. Each FP atom is a fragment of the original U/Pu atom, and is either a nonradioactive "stable" isotope, or else it is the radioactive "parent" of a "daughter" atom. Then, the daughter atom can either be stable, or it can be the parent of yet another generation of daughter. For each FP isotope, its atoms can be present from both mechanisms - some of its atoms may have been formed directly, and while others may be the decay daughters which originated as some other FP isotope.

Six fission products are listed in the SRS “1S Manual" Waste Acceptance Criteria 3.10 (WAC) ${ }^{3}$ :

- selenium, Se-79, which decays to bromine':

As-79 (half life of 9 minutes) $\rightarrow-\rightarrow$ Se-79 $(65,000$ years) $\rightarrow$ Br-79

- strontium, $\mathrm{Sr}-90$, which decays to niobium ${ }^{1}$ :

$\mathrm{Kr}-90$ (half life of 32.3 seconds) $\rightarrow->\mathrm{Rb}-90^{\mathrm{m}}$ (258 seconds) \& Rb-90 (157 seconds) --->

Sr-90 (28.6 years) $\rightarrow$ Y -90 (64.1 hours) $\rightarrow$ Zr-90 (14.6 hours) $\rightarrow$ Nb-90

- technetium, Tc-99, which decays to ruthenium ${ }^{1}$ :

Mo-99 (half life of 66.0 hours) $\rightarrow$ Tc-99m (6.0 hours) \& Tc-99 (213,000 years) $\rightarrow->$ Ru-99 
WSRC-TR-94-0292

Rev. 0 (6/30/94)

Page 4 of 17

- tin, Sn-126, which decays to tellurium ${ }^{1}$ :

Sn-126 (half life of 100,000 years) $\rightarrow$ Sb-126m (19 minutes) \& Sb-126 (12.4 days) $\rightarrow$ Te-126

- iodine, I-129, which decays to xenon ${ }^{1}$ :

Sb-129 (half life of 4.4 hours) $\rightarrow$ Te-129m (33.6 days) \& Te-129 (69.6 minutes) $\rightarrow$

I-129 $(15,700,000$ years $) \rightarrow$ Xe-129

- cesium, Cs-137, which decays to barium ${ }^{1}$ :

Xe-137 (half life of 3.8 minutes) $\rightarrow$ Cs-137 (30.17 years) $\rightarrow$ Ba-137m $(2.52 \mathrm{~min}) \rightarrow \mathrm{Ba}-137$

Characterizing these FP's in HLW supernate involves process knowledge about their production (in the nuclear reactors) and their subsequent behavior (as impacted by process chemistry).

\section{Fission Products Formed in SRS Reactor Assemblies}

In a nuclear reactor, the amount of each FP isotope produced depends primarily on two factors. First is the fissionable atom isotope distribution (e.g., the \% of U-233, $-235,-238 ; \mathrm{Np}-237 ; \mathrm{Pu}-238,-239$, etc). This is largely synonymous with various fuel/target assemblies (e.g., Mark-16, $-22,-31 \mathrm{~A},-31 \mathrm{~B},-53 \mathrm{~A}$, offsite fuel). The second factor that determines FP production is the reactor operating conditions (e.g., flux rate, megawatt-days, etc). Table 1 shows the amount of each of the six FPs generated in each type of assembly (i.e., Ci/assembly), as determined by reactor production-depletion calculations for the DWPF design basis ${ }^{2}$. The different assemblies contain either enriched U-235 (the Mark-16's and a part of the Mark-22 assembly, which is the reactor fuel), or depleted U-238 (the Mark-31A's and -31B's, which produce Pu239), or Np-237 (the Mark-53A's, which produce $\mathrm{Pu}-238$ ). The conclusions drawn from Table 1 are:

1) For each isotope, the range between the lowest and highest amount of curies varies widely between the various assemblies (i.e., by factors of $19 x-145 x$ ). However, this is largely due to differences in the total amount of FP isotopes in various assemblies. Thus the apparent variability is greatly reduced by tracking the isotope ratios, e.g., the "(Ci of isotope $\left.\mathrm{FP}_{\mathrm{x}}\right) /(\mathrm{Ci}$ of Cs-137)" -- these vary over a relatively narrow range (i.e., $<3 \mathrm{x}$ ). For each isotope, a wide variability is seen in the " $\mathrm{Ci} /$ assembly" rows, compared to the lesser variations in the " $\mathrm{Ci} / \mathrm{Ci}$ ratio" rows.

(Note: In this document, the term "Ci/Ci ratio" will always mean the ratio of that FP to Cs-137.) The consistent $\mathrm{Ci} / \mathrm{Ci}$ ratios mean that the exact origin of a given waste is not highly significant. That is, a waste container contaminated with HM supernate (from Mark-16's, -22 's, and -53 A's processed in $\mathrm{H}$-area) will be similar to a container contaminated with PUREX supernate (from Mark-31A's and 31B's processed in F-area). Therefore, the "supernate contaminated" waste stream does not need to be subdivided and tracked individually. The next two sections of this report deal with the "average" waste composition, and then the variability will be addressed in the "maximum" waste composition section.

2) The $\sim 60$ year span of SRS's operation (from 1953 until DWPF completes operation 2015) is about twice the $\sim 30$ year half live of $\mathrm{Sr}-90$ and $\mathrm{Cs}-137$. Therefore (holding other variables constant) the age of a particular waste can vary the isotope $\mathrm{Ci} / \mathrm{Ci}$ ratios for the long lived FPs by a factor of 2-4.

Comparing the "5 year" rows (in Table 1 ) with the " 15 year" rows shows this over a shorter time.

\section{Reactor Assembly Fission Yield Isotope Distribution}

The relative quantity ${ }^{2}$ of each type of assembly processed through the Separations canyons and the subsequent waste volumes generated (shown in Table 1) can be used to calculate the average composition of HLW waste (shown below) that results from processing these assemblies. The 1S manual's Waste Acceptance Criteria ${ }^{3}$ (WAC) specifies the amount of each isotope allowed in a waste package -- these 
WSRC-TR-94-0292

Rev. 0 (6/30/94)

Page 5 of 17

values are called the Package Administrative Criteria (PAC). For comparison with the PAC, assume that a package contains enough "average assembly" waste to have reached the PAC for Cs-137 (i.e., $0.266 \mathrm{gal}$ ):

\begin{tabular}{|c|c|c|c|c|c|}
\hline & $\begin{array}{c}15 \text { year aged } \\
\text { "avg assembly" } \\
\text { waste composition } \\
\text { Ci / gal } \\
\end{array}$ & $\begin{array}{c}\text { hypothetical package } \\
\text { containing } 0.266 \text { gal of } \\
\text { "avg assembly" waste } \\
\mathrm{Ci} / \text { package } \\
\end{array}$ & $\begin{array}{l}\text { WAC } 3.10 \\
\text { PAC values } \\
\text { Ci / package }\end{array}$ & $\begin{array}{c}\text { ratio of } \\
\text { package / PAC }\end{array}$ & $\begin{array}{l}\text { vaste volume req' } \\
\text { for each FP to } \\
\text { equal its PAC } \\
\text { gal } \\
\end{array}$ \\
\hline Se-79 & 0.0000161 & 0.00000429 & 0.00052 & 0.00824 & 32.3 \\
\hline Sr-90 & 2.68 & 0.713 & 1.1 & 0.649 & 0.411 \\
\hline Тc-99 & 0.000553 & 0.000147 & 0.00017 & 0.867 & 0.307 \\
\hline $\mathrm{Sn}-126$ & 0.00000171 & 0.000000456 & 0.00029 & 0.00157 & 169. \\
\hline$I-129$ & 0.000000942 & 0.000000251 & 0.000000083 & 3.02 & 0.088 \\
\hline Cs-137 & 2.85 & 0.76 & 0.76 & 1. & 0.266 \\
\hline
\end{tabular}

These supernate compositions and volumes are for fresh waste (i.e., as received from Separations). After the subsequent volume reduction in the Tank Farm evaporators, the waste concentrations are several fold higher, so the volume required to equal the PAC would be proportionately lower. For example, Cs-137 in the tank farm's average supernate is $5.05 \mathrm{Ci} / \mathrm{gal}$ (126.9 million $\mathrm{Ci}^{17}$, in 25.1 million gallons ${ }^{17 \mathrm{a}}$ ), with a maximum of $44 \mathrm{Ci} / \mathrm{gal}^{15}$.

A useful way to compare the waste stream's composition to the $\mathrm{PAC}$ values involves the isotope ratios, i.e., $\mathrm{Ci}$ of $\mathrm{FP}_{\mathrm{x}}$ per $\mathrm{Ci}$ of $\mathrm{Cs}-137$. If the waste stream's $\mathrm{Ci} / \mathrm{Ci}$ ratios are all less than the $\mathrm{PAC}$ 's $\mathrm{Ci} / \mathrm{Ci}$ ratios, then Cs-137 is the limiting isotope. For any isotope, if the waste stream's $\mathrm{Ci} / \mathrm{Ci}$ ratio is higher than the PAC's $\mathrm{Ci} / \mathrm{Ci}$ ratio, then the allowable $\mathrm{Cs}-137$ content would be reduced proportionately, so the package's content of each isotope remains within its PAC value. Comparing the "average assembly" $\mathrm{Ci} / \mathrm{Ci}$ ratios with the $\mathrm{PAC} \mathrm{Ci/Ci} \mathrm{ratios:}$

\begin{tabular}{|c|c|c|c|c|}
\hline & $\begin{array}{c}\text { "average assembly" } \\
\text { curie ratios } \\
\mathrm{Ci} / \mathrm{Ci} \text { Cs-137 } \\
\end{array}$ & $\begin{array}{c}\text { PAC } \\
\text { curie ratios } \\
\mathrm{Ci} / \mathrm{Ci} \text { Cs-137 } \\
\end{array}$ & $\begin{array}{c}\text { ratio of } \\
\text { "avg assembly" ratio } \\
\text { to the PAC ratio }\end{array}$ & $\begin{array}{c}\text { available } \\
\text { margin } \\
\text { factor } \\
\end{array}$ \\
\hline Se-79 / Cs-137 & 0.00000564 & 0.000684 & 0.00824 & 121. \\
\hline $\mathrm{Sr}-90 / \mathrm{Cs}-137$ & 0.939 & 1.45 & 0.649 & 1.54 \\
\hline Tc-99 / Cs-137 & 0.000194 & 0.000224 & 0.867 & 1.15 \\
\hline $\mathrm{Sn}-126 / \mathrm{Cs}-137$ & 0.000000600 & 0.000382 & 0.00157 & 636. \\
\hline I-129/Cs-137 & 0.000000330 & 0.000000109 & 3.02 & 0.331 \\
\hline $\mathrm{Cs}-137 / \mathrm{Cs}-137$ & 1. & 1. & 1. & 1. \\
\hline
\end{tabular}

These comparisons lead to these conclusions for packages contaminated with "average assembly" waste:

1) When the package reaches the PAC for Cs-137, it will only contain trace amounts of Se-79 and Sn-126 (only $0.82 \%$ and $0.16 \%$ of their PAC values respectively). A waste package would have to contain a large volume of supernate to exceed the PAC values (i.e., 32 and 169 gal respectively), and by that time the package would have already exceeded the Cs-137 PAC value by $121 \mathrm{x}-636 \mathrm{x}$. This shows that these two isotopes are of no concern.

2) When the package reaches the PAC for Cs-137, then Sr-90 and Tc-99 will still meet their PAC, but not by large margins.

3) When the package reaches the PAC for Cs-137, the I-129 will already have exceeded its PAC by $200 \%$. In order for the waste package to meet I-129's PAC value, it's Cs-137 content would have to be limited to 0.331 PAC.

The $\mathrm{Ci} / \mathrm{Ci}$ ratio concept also parallels the tank farm's waste compliance program: i.e., to measure a waste package's external radiation dose rate, determine the Cs-137 content, and calculate the remaining isotope's contents by their predetermined "scaling factors" (i.e., the $\mathrm{Ci} / \mathrm{Ci}$ composition ratios). If a waste stream's isotope ratios exceed the PAC ratios (i.e., when the "ratio of ratios" exceeds 1), then the allowable 
WSRC-TR-94-0292

Rev. 0 (6/30/94)

Page 6 of 17

radiation rate must be reduced until the Cs-137 content is low enough that the package's calculated inventory for all the other FPs will each meet their PAC values.

\section{Alternative Fission Yield Isotope Distribution}

Table 1 is based on Chandler's 1980 reactor fission product yield calculations ${ }^{2}$ (done for the DWPF design basis), and this subject has recently been revisited by Webb ${ }^{2 a}$ (for the SRS waste certification program). Comparing these calculations shows that both obtained essentially the same results (they used the same computer codes). Webb added one old style assembly (i.e., Mark-5E) and omitted two others (i.e., Mark$31 \mathrm{~B},-53 \mathrm{~A})$. Webb showed several decay times, where his case of 20 years is most comparable to Chandler's 15 years. During those additional 5 years, a noticeable portion of the Sr- 90 and Cs-137 would decay (they each have half lives of $\sim 30$ years), so Webb's $\mathrm{Ci} / \mathrm{Ci}$ ratios are generally slightly higher than Chandler's. Webb's calculation supports the conclusion that fission yield does not produce sufficient Se79 and Sn-126 to limit the contents of waste packages. As stated in Webb's report ${ }^{2 a}$ :

"These $(\mathrm{Ci} / \mathrm{Ci})$ relationships are true only if, subsequent to production, there have been no physical or chemical processes which preferentially separate one element relative to another. It is valid however, to combine data on chemical/physical separation processes with production data in order to justify a ratio different from those reported here, which are based solely on production data".

The next section develops the chemical/physical justification for reducing the Sr-90, Tc-99, and I-129 activity levels estimated for actual waste tank supernate.

\section{Average Waste Tank Supernate}

If all the FP atoms in the fuel/target assemblies went to the waste tanks and stayed in the supernate, then "average assembly" $\mathrm{Ci} / \mathrm{Ci}$ isotope ratios would actually apply to "supernate contaminated" waste. In reality however, there are two "partition factors" which impact the supernate's $\mathrm{Ci} / \mathrm{Ci}$ ratios: not all the FPs go the waste tanks, and not all the FPs stay in the supernate:

1) When Separations dissolves the assemblies in nitric acid, part of the iodine is volatilized into the dissolver off-gas system. Part of that volatile I-129 is collected as silver iodide (on silver coated Beryl saddles). Originally, the silver iodide coating was dissolved and flushed to the waste tanks; later the coated rings either went to Solid Waste or remain in Separations ${ }^{10}$. In the PUREX process (i.e., in Farea, and in $\mathrm{H}$-area before 1960), an estimated $15-20 \%$ of the I-129 went to the waste tanks; compared to the $95-98 \%$ estimated for the HM process (i.e., for $\mathrm{H}$-area since 1960$)^{10}$.

Thus there are three routes whereby the waste tanks do not contain all the I-129 that was originally produced in the assemblies: venting to atmosphere, disposal, and storage. Of the $39 \mathrm{Ci}$ of I-129 produced through $1974,60 \%$ is estimated to have not gone to the waste tanks ${ }^{10}$. These "losses" reduce the I-129/Cs-137 ratio for "supernate contaminated" waste to $40 \%$ of the average assembly $\mathrm{Ci} / \mathrm{Ci}$ ratio value (which was shown in Table 1).

In the waste tank's caustic environment, the I-129 will be present as non-volatile soluble salts (i.e., sodium iodide, and sodium iodate) ${ }^{10,12}$. Chemically, the behavior of iodine will be analogous to chlorine. In acid solutions, chlorine is the semi-volatile hydrochloric acid $(\mathrm{HCl})$; but when neutralized, it becomes sodium chloride (i.e., table salt, $\mathrm{NaCl}$ ). Likewise, in the acidic Separations process, iodine is a semi-volatile molecule $(\mathrm{HI})$; and then it becomes nonvolatile $(\mathrm{NaI})$ in the waste tanks.

If iodine were volatile in caustic solutions, then the tank farm evaporators would have either sent the iodine to the Effluent Treatment Facility (if it condensed in the overheads stream), or it would have been vented to atmosphere (if it didn't condense). The available sample data (discussed later) indicates 
WSRC-TR-94-0292

Rev. 0 (6/30/94)

Page 7 of 17

that iodine "concentrates" in the evaporators (like cesium). This confirms that the iodine species present in the waste tanks is not volatile.

Aside from iodine, essentially $100 \%$ of the other FP isotopes in the assemblies do go to the waste tanks. Only trace amounts are "lost" to the environment or to Separation's (or Reactor's) solid waste streams.

2) Many other isotopes are only slightly soluble in the waste tank's highly caustic environment, so a large fraction of those curies ends up in the sludge layer. Depending on the FP isotope's chemical behavior, the supernate may only contain part of the original activity. The portion can range from essentially everything (e.g., I-129, Cs-137 = 100\%), to a moderate amount (e.g., Tc-99 =57\%, Se-79=10\%, Sn$126=4 \%$ ), or a very small fraction (e.g., Sr-90 $=0.025 \%$ ).

The supernate portions (i.e., "partition factors") were determined empirically, from sample analyses of supernate samples taken during development of the DWPF,8. Thus the "supernate fraction" includes both the true chemical solubility and any "physical" effects such as suspended colloidal particulate.

Accounting for these two factors, the $\mathrm{Ci} / \mathrm{Ci}$ ratios of "average supernate" waste are different than those of "average assembly" waste:

\begin{tabular}{|c|c|c|c|c|c|}
\hline 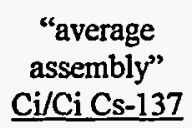 & $\begin{array}{c}\text { partition } \\
\text { fractions to } \\
\text { waste\&supernate }\end{array}$ & 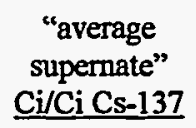 & $\begin{array}{c}\text { PAC } \\
\text { ratios } \\
\text { Ci/Ci Cs-137 } \\
\end{array}$ & $\begin{array}{l}\text { ratio of the } \\
\text { "avg supern" ratio } \\
\text { to the PAC ratio }\end{array}$ & $\begin{array}{c}\text { available } \\
\text { margin } \\
\text { factor }\end{array}$ \\
\hline $5.64 \mathrm{E}-06$ & 1. \& 0.1 & $5.64 \mathrm{E}-07$ & $6.84 \mathrm{E}-04$ & 0.000824 & 1,510 . \\
\hline $9.39 \mathrm{E}-01$ & 1. \& 0.00025 & $2.35 \mathrm{E}-04$ & 1.45 & 0.000162 & 6,170 . \\
\hline $1.94 \mathrm{E}-04$ & 1. \& 0.57 & $1.10 \mathrm{E}-04$ & $2.24 \mathrm{E}-04$ & 0.493 & 2.02 \\
\hline $6.00 \mathrm{E}-07$ & 1. \& 0.04 & $2.40 E-08$ & 3.82E-04 & 0.0000629 & 15,900 . \\
\hline $3.30 \mathrm{E}-07$ & $0.4 \& 1$ & $1.32 \mathrm{E}-07$ & $1.09 \mathrm{E}-07$ & 1.21 & 0.827 \\
\hline 1. & 1. \& 1 . & 1. & 1. & 1. & 1. \\
\hline
\end{tabular}

Accounting for these two factors leads to several conclusions:

1) The two isotopes which were un-important (Se-79 and Sn-126) become even less significant.

2) One of the previously marginal isotopes (Sr-90) becomes totally un-important.

3) The other previously marginal isotope (Tc-99) remains marginal.

4) The isotope which previously appeared to be the actual limit (I-129) remains so, although to a somewhat lesser extent. To keep the package I- 129 content within its PAC criteria, the Cs-137 content would have to be limited to $82 \%$ of its PAC.

\section{Maximum Waste Tank Supernate}

As was noted previously, for a given $\mathrm{FP}$ isotope, variations in the $\mathrm{Ci} / \mathrm{Ci}$ ratios between types of assemblies is relatively small, and those variations do not materially change the above conclusions. This is demonstrated by hypothesizing a "maximum" supernate which contains each $\mathrm{FP}$ at the highest $\mathrm{Ci} / \mathrm{Ci}$ ratio produced in any type of assembly (i.e., the "max" column shown in Table 1):

\begin{tabular}{|c|c|c|c|c|c|c|}
\hline & $\begin{array}{c}\text { "maximum } \\
\text { assembly" } \\
\text { Ci/Ci Cs-137 } \\
\end{array}$ & $\begin{array}{c}\text { partition } \\
\text { fractions to } \\
\text { waste\&supernate }\end{array}$ & $\begin{array}{c}\text { "maximum } \\
\text { supernate" } \\
\text { Ci/Ci Cs-137 } \\
\end{array}$ & $\begin{array}{c}\text { PAC } \\
\text { ratios } \\
\text { Ci/Ci Cs-137 } \\
\end{array}$ & $\begin{array}{l}\text { ratio of the } \\
\text { "max supern" ratio } \\
\text { to the PAC ratio }\end{array}$ & $\begin{array}{c}\text { available } \\
\text { margin } \\
\text { factor } \\
\end{array}$ \\
\hline Se-79/Cs-137 & $5.81 E-06$ & 1. \& 0.1 & $5.81 \mathrm{E}-07$ & $6.84 \mathrm{E}-04$ & 0.000849 & 1,180 \\
\hline Sr-90 / Cs-137 & $9.74 \mathrm{E}-01$ & 1. \& 0.00025 & $2.43 E-04$ & 1.45 & 0.000168 & 5,940 \\
\hline Tc-99/Cs-137 & $2.00 \mathrm{E}-04$ & 1. \& 0.57 & $1.14 \mathrm{E}-04$ & $2.24 \mathrm{E}-04$ & 0.510 & 1.96 \\
\hline $\mathrm{Sn}-126 / \mathrm{Cs}-137$ & $1.30 \mathrm{E}-06$ & 1. \& 0.04 & $5.21 \mathrm{E}-08$ & $3.82 E-04$ & 0.000136 & 7,330 . \\
\hline I-129 / Cs-137 & $5.86 \mathrm{E}-07$ & $0.4 \& 1$ & $2.35 \mathrm{E}-07$ & $1.09 \mathrm{E}-07$ & 2.15 & 0.466 \\
\hline $\mathrm{Cs}-137 / \mathrm{Cs}-137$ & 1. & 1. \& 1 & 1. & 1. & 1. & 1. \\
\hline
\end{tabular}


WSRC-TR-94-0292

Rev. 0 (6/30/94)

Page 8 of 17

Comparing these "maximum supernate" $\mathrm{Ci} / \mathrm{Ci}$ ratios with the $\mathrm{PAC}$ ratios shows that:

1) $\mathrm{Se}-79, \mathrm{Sr}-90$, and $\mathrm{Tc}-99$ are essentially un-affected (their "maximum assembly" $\mathrm{Ci} / \mathrm{Ci}$ ratios are only $\sim 3 \%$ higher than the "average assembly" $\mathrm{Ci} / \mathrm{Ci}$ ratios).

2) $\mathrm{Sn}-126$ could increase by $121 \%$ ( $\max =2.21$ *avg), so the available margin before $\mathrm{Sn}-126$ becomes the limiting isotope would "only" be 7,330x instead of $15,900 x$.

3) I-129 could increase by $78 \%$ ( $\max =1.78 * a v g)$, which would raise the "supernate/PAC" ratio from 1.21 to 2.15 . Covering this possibility would require limiting the waste packages to $46 \%$ of the Cs- 137 criteria, instead of $82 \%$.

The WAC says that "on average, each package from a given waste stream will meet the (PAC)". The interpretation of the term "on average" will determine whether the 1.78 factor needs to be applied.

Over a long enough time period, the "average waste package" could be presumed to contain "average supernate". But over a sufficiently short time span, there is a possibility that disproportionate amounts of waste (e.g., resulting from non-uniform work loads) could be generated from tanks with high ratios of I-129/Cs-137. The PAC could be exceeded over that particular time span.

\section{Inventory, Partition Factor, and Sample Data}

The previous section developed the isotope $\mathrm{Ci} / \mathrm{Ci}$ ratios expected for supernate contaminated waste, as based on the reactor's calculated production rates for the various fission products, and the subsequent impacts of process chemistry. This section compares those expectations to available sample data for these isotopes in actual waste tank supernate:

\section{Se-79}

Tank 50 contains decontaminated salt solution which was produced during the 1983 demonstration of the ITP process. One sample (taken $6 / 1 / 89$ ) was analyzed ${ }^{4}$ for Se-79. The result $(0.185 \mathrm{nCi} / \mathrm{gm}$ of salt) corresponds to $8.4 \mathrm{E}-7 \mathrm{Ci} / \mathrm{gal}$ (for a solution having a 1.2 density), so the waste package would have to contain 615 gallons before it could exceed the 5.2E-4 Ci PAC value. Note that the ratio of Se-79/Cs- 137 in tank 50 is not indicative of supernate contaminated waste, since the ITP process had chemically removed (i.e., precipitated) almost all of the Cs-137 activity.

Table 4 shows several analyses obtained during previous waste characterization efforts (mostly related to developing the DWPF flowsheet) and during preparation of feed solutions for the 1982 demo of the ITP process (the tank 24 samples).

These analyses do not contradict the previous conclusion that Se-79 will not be a limiting isotope.

\section{Sr-90}

The total waste tank inventory of $\mathrm{Sr}-90$ is estimated ${ }^{17}$ to be $122,000,000 \mathrm{Ci}$. Only a small fraction $(0.00025)$ of the $\mathrm{Sr}-90$ is expected ${ }^{5}$ to partition into the supernate $(30,500 \mathrm{Ci})$, and the remainder will be in the sludge. This implies that the 25.1 million gallons of supernate ${ }^{17 a}$ will average $0.00121 \mathrm{Ci} / \mathrm{gal}$, so a waste package would have to contain 905 gal to exceed the $1.1 \mathrm{Ci}$ PAC value.

Special supernate samples ${ }^{6}$ were taken from 9 waste tanks in July and November 1992 . As shown in Table 2, the Sr -90 concentration averaged $1.76 \mathrm{E} 6 \mathrm{~d} / \mathrm{m} / \mathrm{ml}(0.0030 \mathrm{Ci} / \mathrm{gal})$. At this concentration, a waste package would have to contain 363 gallons of supernate before it exceeds the 1.1 Ci PAC. Of the 9 samples, the average $\mathrm{Sr}-90 / \mathrm{Cs}-137$ ratio is $0.00057 \mathrm{Ci} / \mathrm{Ci}$. This is slightly higher $(2.5 \mathrm{x})$ than the "fission yield and partition factor" ratio of $0.00023 \mathrm{Ci} / \mathrm{Ci}$, but is still well below the $1.45 \mathrm{Ci} / \mathrm{Ci}$ ratio where Cs-137 would cease to be the limiting isotope. 
WSRC-TR-94-0292

Rev. $0(6 / 30 / 94)$

Page 9 of 17

Waste tank supernate samples are taken routinely as part of the tank corrosion control program, and 33 of these have been analyzed ${ }^{15}$ for both Sr-90 and Cs-137 (see Table 3). The min/avg/max values shown in Table 3 do not include one sample (i.e., Tank 23 in 10/71), where the unusually low Cs-137 content is obviously suspect. The remaining 32 samples averaged $0.00228 \mathrm{Ci} / \mathrm{gal}$ for $\mathrm{Sr}-90$, so a waste package would have to contain $482 \mathrm{gal}$ of this supernate before it would exceed the 1.1 $\mathrm{Ci}$ PAC. The average Sr-90/Cs-137 ratio for these samples $(0.00103 \mathrm{Ci} / \mathrm{Ci})$ is $4.4 \mathrm{x}$ higher than the "fission yield and partition factor" ratio $(0.000235 \mathrm{Ci} / \mathrm{Ci})$, but is still well below the ratio where $\mathrm{Cs}-137$ would cease to be the limiting isotope $(1.44 \mathrm{Ci} / \mathrm{Ci})$.

Table 4 shows several analyses obtained during previous waste characterization efforts (mostly related to developing the DWPF flowsheet) and during preparation of feed solutions for the 1982 demo of the ITP process (the tank 24 samples). These results indicate that Sr-90 is well below the PAC.

These analyses do not contradict the previous conclusion that $\mathrm{Sr}-90$ will not be a limiting isotope.

Tc-99

As shown in Table 4, twelve supernate samples ${ }^{8}$ ranged from 0.00015 to $0.0010 \mathrm{Ci} /$ gallon and averaged $0.00036 \mathrm{Ci} / \mathrm{gal}$ (normalized to a supernate containing $400 \mathrm{gm}$ salt/liter), so a waste package would have to contain 0.47 gal to exceed the $0.00017 \mathrm{Ci}$ PAC value.

Supernate samples ${ }^{6}$ were taken from 9 waste tanks in July and November 1992. As shown in Table 2, the Tc-99 concentration averaged $4.9 \mathrm{E} 5 \mathrm{~d} / \mathrm{m} / \mathrm{ml}(0.00084 \mathrm{Ci} / \mathrm{gal})$. At this concentration, a waste package would have to contain 0.20 gallons of supernate before it would exceed the WAC value of $0.00017 \mathrm{Ci}$. Of these 9 samples, the average Tc-99/Cs-137 ratio is $0.00016 \mathrm{Ci} / \mathrm{Ci}$. This agrees well with the "fission yield and partition factor" ratio of $0.00011 \mathrm{Ci} / \mathrm{Ci}$, and also meets the $0.000224 \mathrm{Ci} / \mathrm{Ci}$ ratio which allows $\mathrm{Cs}-137$ to be the limiting isotope.

Saltcake samples ${ }^{16}$ taken from two locations in tank 41 were found to contain $4.0 \mathrm{E}-4 \& 1.75 \mathrm{E}-4 \mathrm{Ci}$ of $\mathrm{Cs}-137 / \mathrm{gm}$ of salt, and $1.2 \& 3.8 \mathrm{E}-8 \mathrm{Ci}$ of Tc-99/gm of salt. This $0.000263 \mathrm{Ci} / \mathrm{Ci}$ ratio slightly exceeds the 0.000224 ratio that would allow Cs-137 to be the limiting isotope.

Waste tank supernate samples are taken routinely as part of the tank corrosion control program, and 21 of these have been analyzed ${ }^{15}$ for both Tc-99 and Cs-137 (see Table 3). Note that the $\mathrm{min} / \mathrm{avg} / \mathrm{max}$ values shown in Table 3 do not include the 36 samples of tank 50H -- because 1) its Cs-137 was chemically removed by the ITP demo in 1983 (thus changing its $\mathrm{Ci} / \mathrm{Ci}$ ratios) and 2) the contents of tank 50 have been dormant, so the repeated samples would skew the average. The min/avg/max values in Table 3 also exclude one sample (i.e., tank 20 on 8/82), where the unusually low Cs-137 content is obviously suspect (note that a sample taken 6 days later had a normal Cs- 137 content, although that sample wasn't analyzed for Tc-99). The remaining 20 analyses average $0.00049 \mathrm{Ci} / \mathrm{gal}$ for Tc-99, so a waste package would have to contain $0.346 \mathrm{gal}$ of this supernate before it would exceed the $0.00017 \mathrm{Ci}$ $\mathrm{PAC}$ value. The average Tc-99/Cs-137 ratio of $0.00019 \mathrm{Ci} / \mathrm{Ci}$ agrees well with the 0.000194 ratio determined by the "average assembly" fission yield (it is $1.64 \mathrm{x}$ higher than the 0.000116 ratio determined by accounting for the expected partition factor), and it also meets the $0.000224 \mathrm{Ci} / \mathrm{Ci}$ ratio that allows Cs- 137 to be the limiting isotope. The Tc-99 abundance shown in Table 3 could be related to analytical difficulties, or it may reflect the impact of other types of fuel/target assemblies (or their operating history) which are not included in the reactor fission yield calculations ${ }^{2,2 a}$.

These analyses confirm the previous conclusion that Tc-99 is expected to be present in supernate contaminated waste packages, and they agree reasonably well with the "fission yield and partition factor" isotope ratio of $0.00011 \mathrm{Ci} / \mathrm{Ci}$. 
WSRC-TR-94-0292

Rev. $0(6 / 30 / 94)$

Page 10 of 17

Note: Ref 9 discusses Tc- 99 from a site-wide perspective, and ref 8 details the tank farm inventory and technetium's behavior/chemistry.

\section{$\mathrm{Sn}-126$}

Supernate samples ${ }^{6}$ were taken from 9 waste tanks in July and November 1992. As shown in Table 2, the $\mathrm{Sn}-126$ concentration averaged $4.93 \mathrm{E} 3 \mathrm{~d} / \mathrm{m} / \mathrm{ml}(8.5 \mathrm{E}-6 \mathrm{Ci} / \mathrm{gal})$, so a waste package would have to contain $34.1 \mathrm{gal}$ before it would exceed the $2.9 \mathrm{E}-4 \mathrm{Ci}$ PAC. The average Sn-126/Cs-137 ratio of $1.6 \mathrm{E}-6 \mathrm{Ci} / \mathrm{Ci}$ :

- is $2.7 \mathrm{x}$ higher than the $6.0 \mathrm{E}-7$ ratio determined by the "average assembly" fission yield (and is $67 \mathrm{x}$ higher than the $2.4 \mathrm{E}-8$ ratio determined by accounting for the expected partition factor).

- is still well within the $3.81 \mathrm{E}-4 \mathrm{Ci} / \mathrm{Ci}$ ratio which allows $\mathrm{Cs}-137$ to be the limiting isotope.

The Sn-126 abundance shown in Table 2 could be related to analytical difficulties, or it may reflect the impact of other types of fuel/target assemblies (or their operating history) which are not included in the reactor fission yield calculations ${ }^{2,2 a}$.

These analyses do not contradict the previous conclusion that Sn-126 will not be a limiting isotope.

\section{I-129}

Dissolved salt and supernate from tank $24 \mathrm{H}$ was used in the full-scale demonstration of the In-Tank Precipitation process in 1983. That supernate was used to develop an analytical method (which involves Cs-137 precipitation, and ion exchange of the iodine) which found that the I-129 was <1.7E-9 $\mathrm{Ci} / \mathrm{gal}$ (i.e., less than the $0.45 \mathrm{pCi} / \mathrm{ml}$ detection capability) ${ }^{11}$.

Table 4 shows several waste tank analyses ${ }^{12}$ for I-129. Compared to fresh supernate, the $3 x$ higher I129 content found in the concentrated supernate is directly related to the volume reduction (boildown) achieved by the tank farm evaporators. The low values found in the salt samples are also indicative of the high solubility of iodine (i.e., its reluctance to crystallize into the salt phase). A waste package would only have to contain 0.075 gal of the $1.1 \mathrm{E}-6 \mathrm{Ci} / \mathrm{gal}$ supernate to exceed the $8.3 \mathrm{E}-8 \mathrm{Ci} \mathrm{PAC}$ value. As expected based on a $3 x$ concentration factor in the evaporators, this is $\sim 1 / 3$ of the $0.22 \mathrm{gal}$ value determined by "fission yield and partition factor".

The total waste tank inventory of I-129 has been estimated ${ }^{12}$ to be $9.1 \mathrm{Ci}$. This is comparable to the $\sim 10 \mathrm{Ci}$ introduced to the atmosphere by nuclear weapons testing, or to the environment's $\sim 40 \mathrm{Ci}$ natural inventory ${ }^{13}$. Note: Ref 13 discusses I-129 from a site-wide perspective, and ref 12 details the tank farm inventory and iodine's behavior/chemistry.

These sample results confirm the previous conclusion that I-129 is expected to be present in supernate contaminated waste packages. Relative to its PAC value, I-129 will limit the packages to an extent similar to Cs-137.

\section{Cs-137}

The total waste tank inventory of Cs-137 is estimated ${ }^{17}$ to be $1.269 \mathrm{E} 8 \mathrm{Ci}$. Part of the Cs-137 is associated with interstitial supernate in the layers of sludge and saltcake, but most ${ }^{5}$ will be in the 25.1 million gallons of supernate ${ }^{17 a}$, which would thus average $5.05 \mathrm{Ci} / \mathrm{gal}$.

Supernate samples ${ }^{6}$ were taken from 9 waste tanks in July and November 1992. As shown in Table 2, the $\mathrm{Cs}-137$ concentration averaged $3.08 \mathrm{E} 9 \mathrm{~d} / \mathrm{m} / \mathrm{ml}(5.3 \mathrm{Ci} / \mathrm{gal})$. At this concentration, a waste package would have to contain 0.14 gallons of supernate before it would exceed the WAC value of $0.76 \mathrm{Ci}$. 
WSRC-TR-94-0292

Rev. 0 (6/30/94)

Page 11 of 17

Waste tank supernate samples are taken routinely as part of the tank corrosion control program. Chart 1 shows the 470 analyses ${ }^{15}$ which average $2.66 \mathrm{Ci} / \mathrm{gal}$ (they range from 0.000000007 to 44 . $\mathrm{Ci} / \mathrm{gal}$ ). At the average concentration, a waste package would have to contain 0.29 gal to exceed the $0.76 \mathrm{Ci}$ $\mathrm{PAC}$ value.

Note: Ref 14 discussed Cs-137 from a site-wide perspective.

\section{Future Conditions}

The DWPF melter is expected to volatilize Cs-137 more than the other isotopes, so the DWPF recycle stream (which returns to the tank farm) will contain more Cs-137 compared to the other isotopes (i.e., the other isotope $\mathrm{Ci} / \mathrm{Ci}$ ratios will be lower). Thus future supernates, which will consist partially of DWPF recycle, should have (slightly) lower $\mathrm{Ci} / \mathrm{Ci}$ ratios than the values discussed in this document. Therefore it would be conservative to keep using the same dose rate scaling factors derived for the current supernate, as this will (slightly) over-estimate the amounts of other FP isotopes in the waste packages.

Over a sufficiently long time span, the amount of Cs-137 present will eventually decline (due to its 30 year half life) enough that the $\mathrm{Ci} / \mathrm{Ci}$ ratios used for the other FP isotopes will have to be adjusted.

\section{CONCLUSIONS}

Both the fission yield calculations and the available sample data confirm that Se-79, $\mathrm{Sr}-90$, and $\mathrm{Sn}-126$ in supernate contaminated waste will be quite minor relative to the Package Administrative Criteria. When a waste package contains enough supernate to equal the $\mathrm{Cs}-137 \mathrm{PAC}$, it will contain less than $1 / 1000^{\text {th }}$ of the PACs for these three isotopes, thus they will not need to be reported in the package manifest. This applies to both an "average" mix of fuel/target assemblies, and to a hypothetical "maximum" assembly (which contains the worst concentrations of each fission product relative to the amounts of Cs-137).

The Tc-99, I-129, and Cs-137 are all relatively soluble and thus tend to stay in the evaporator's concentrated supernate instead of settling into the sludge layer or crystallizing into the saltcake. Compared to the PAC values, I-129 will be slightly more limiting than Cs-137. This means that the allowable package dose rate should be reduced $20 \%$, such that the package's I-129 content also meets the PAC. When a waste package contains enough supernate to equal the Cs-137 PAC, it will contain $~ 50 \%$ and $120 \%$ of the PAC for Tc-99 and I-129 (respectively). These three isotopes will have to be reported in the package manifest. 
WSRC-TR-94-0292

Rev. 0 (6/30/94)

Page 12 of 17

\section{REEERENCES}

1. The Se-79 decay chain is from "Chart of the Nuclides", G.E./Knolls Lab, 4/88. The others are from appendix B of "External Dose-Rate Conversion Factors for Calculation of Dose to the Public", July 1988, DOE/EH--0070 DE88 014691.

2. "Preliminary Technical Data Summary - DWPF - Stage 2", 12/80, DPSTD-80-39 (specifically, section 13.6 "Radionuclide Compositions", by J.R.Chandler). Note that later versions of this document omit this material (i.e., DPSTD-80-39-2).

2a. "Production Limits for Fission Product Ratios", R.L.Webb, 6/15/94, EPD-CTG-94-0006.

3. "SRS Waste Acceptance Criteria Manual", WSRC-1S (specifically the LAWV column in table 2 of procedure WAC 3.10, rev-1, 5/21/94).

4. Analytical results from TMANorcal, dated 7/15/89; attached to "Tank 50 Sample Results", J.E.Batton, 8/3/89, OPS-DPF-89-0036.

5. "Update of Chemical and Radiochemical Composition of Decontaminated Soluble Waste From the Precipitation Process", J.R.Fowler, 8/6/82, DPST-82-759.

6. "Composition of Tank Farm Supernate Samples", D.D.Walker/et.al., 7/16/93, WSRC-RP-93-1009.

7. "Assessment of Strontium in the S.R.S. Environment", W.H.Carlton/et.al., (no date), WSRC-RP-92-984.

8. "Technetium-99 in SRP High-Level Waste and Saltstone", J.R.Fowler/et.al., 2/24/84, DPST-84-334.

9. "Assessment of Technetium in the S.R.S. Environment", W.H.Carlton/et.al., 7/93, WSRC-TR-93-217.

10. "Estimation of ${ }^{129}$ I Distribution on SRP Separations Processes", W.R.Cornman, 11/21/74, DPST-74-533.

11. "Analysis of Decontaminated Defense Waste Salt Supernate for I-129", J.P.Ryan, 2/23/93, DPST-83-325.

12. "I-129 in SRP High-Level Waste and Saltstone", J.R.Fowler and J.R.Cook, 2/29/84, DPST-84-343.

12a. Personal communications with J.R.Fowler 6/17/94: ref 12 incorrectly reports a value $10 x$ lower for I-129 in tank 15H. The original (correct) data is in notebook DPSTN-3302 pages 69 and 82-83.

13. "Radioiodine in the S.R.S. Environment", M.V.Kantelo/et.al., 1/15/93, WSRC-RP-90-424-2.

14. "Cesium in the S.R.S. Environment", W.H.Carlton/et.al., 3/92, WSRC-RP-92-250.

15. "Radionuclide Sample Analysis of Waste Tanks 1-51", J.A.Pike, 1/24/94, HLW-HLE-94-0328.

16. "Final Report: Analysis of Tank 41H Saltcake Sample \#1 and Comparison to Sample \#1", D.T.Hobbs and C.J.Coleman, 1/26/94, WSRC-TR-94-057.

17. "High Level Waste Engineering Monthly Data Record - October 1993", R.A.Scaggs, 12/13/94, WSRC-RP-93-78-10B.

17a. The tank farm inventory ${ }^{17}$ is $34.01 \mathrm{E} 6$ gal total, consisting of $3.67 \mathrm{E} 6$ gal sludge, $14.09 \mathrm{E} 6$ gal saltcake, and $16.25 \mathrm{E} 6 \mathrm{gal}$ supernate (ranging from ballast water to highly concentrated). Allowing for $60 \%$ of the sludge volume to be interstitial supernate (and $10 \%$ of the saltcake), the total equivalent supernate volume is $25.1 \mathrm{E} 6 \mathrm{gal}$. 


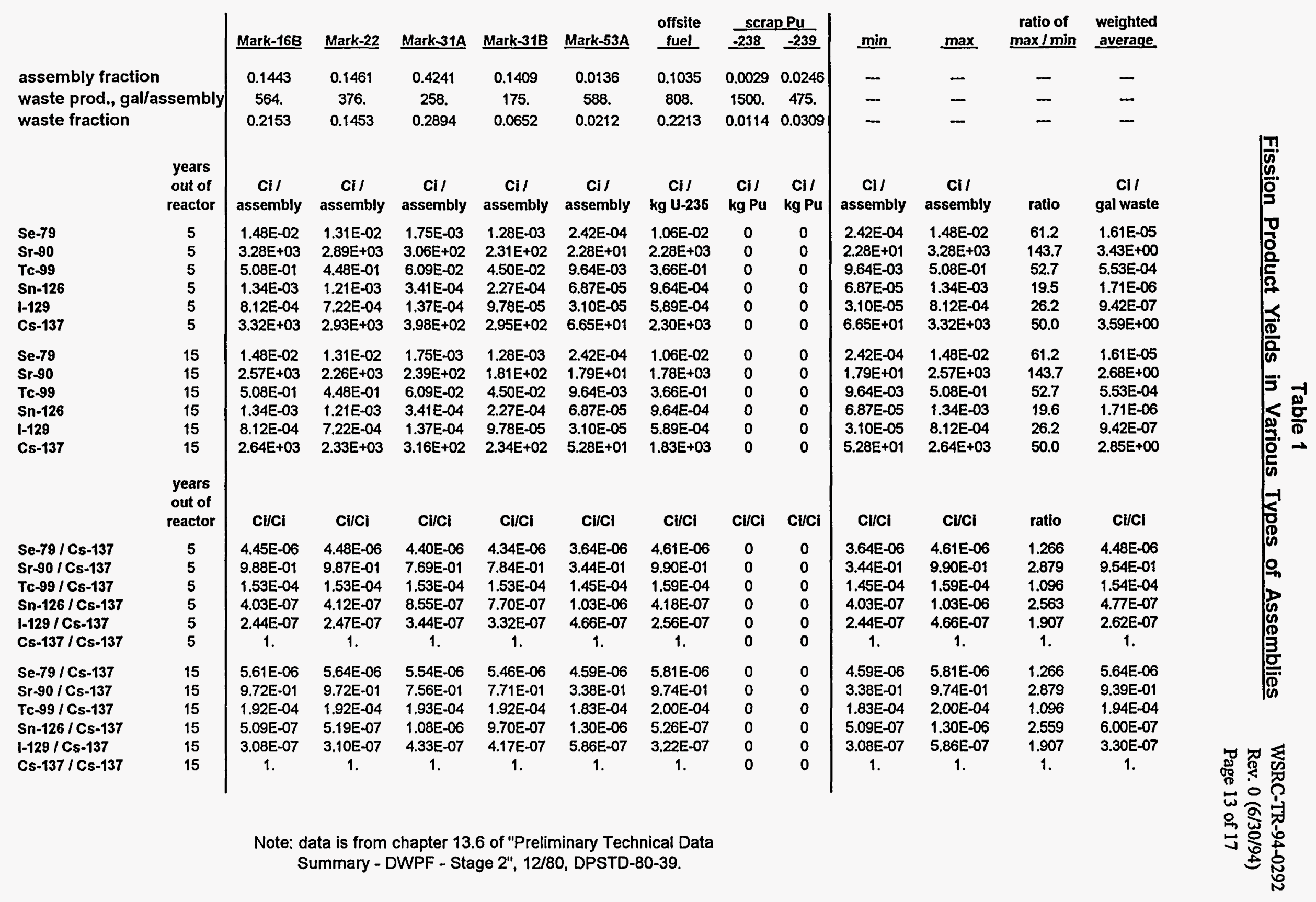


sample

analysis:

Sr-89/90

Tc-99

$\mathrm{Sb}-125$

Sn-126

Cs-134

Cs-137

$\begin{array}{ll}\text { Sr-89/90 / avg } & \text { ratio } \\ \text { Tc-99 / avg } & \text { ratio } \\ \text { Sb-125 / avg } & \text { ratio } \\ \text { Sn-126 / avg } & \text { ratio } \\ \text { Cs-134 / avg } & \text { ratio } \\ \text { Cs-137 / avg ratio }\end{array}$

$\mathrm{Sr}-89 / 90 / \mathrm{Cs}-137 \mathrm{Ci} / \mathrm{Ci}$

Tc-99 / Cs-137 Ci/Ci

Sb-125 / Cs-137 Ci/Ci

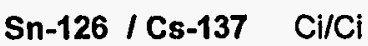

$\mathrm{Cs}-134 / \mathrm{Cs}-137 \mathrm{Ci} / \mathrm{Ci}$

Cs-137/ Cs-137 $\mathrm{Ci} / \mathrm{Ci}$

\begin{tabular}{|c|c|}
\hline avera & $25 \mathrm{~F}$ \\
\hline $1.76 \mathrm{E}+06$ & $6.90 E+04$ \\
\hline $4.89 E+05$ & $3.70 E+05$ \\
\hline $1.23 E+05$ & $7.00 E+02$ \\
\hline $4.93 E+03$ & $5.70 E+03$ \\
\hline $5.54 E+07$ & not detect. \\
\hline $3.08 \mathrm{E}+09$ & $2.50 E+09$ \\
\hline
\end{tabular}

\begin{tabular}{|c|c|}
\hline $26 F$ & $27 F$ \\
\hline $9.10 E+04$ & $7.50 \mathrm{E}+04$ \\
\hline $4.00 E+05$ & $3.10 E+05$ \\
\hline $7.00 E+02$ & $7.00 E+02$ \\
\hline $6.00 E+03$ & $4.90 E+03$ \\
\hline $1.00 E+08$ & not detect. \\
\hline $3.20 E+09$ & $2.20 E+09$ \\
\hline
\end{tabular}

$\frac{28 F}{7.20 E+04}$
$4.00 E+05$
$4.00 E+02$
$6.20 E+03$
$7.40 E+07$
$2.60 E+09$

\begin{tabular}{|c|c|}
\hline $29 \mathrm{H}$ & $30 \mathrm{H}$ \\
\hline $8.50 E+05$ & 1.30E+07 \\
\hline 1.15E+06 & $5.80 E+05$ \\
\hline $4.90 E+04$ & $1.20 \mathrm{E}+05$ \\
\hline $1.00 E+04$ & $4.40 E+03$ \\
\hline $2.00 E+07$ & $1.20 E+08$ \\
\hline $6.50 \mathrm{E}+09$ & $4.80 E+09$ \\
\hline
\end{tabular}

$32 \mathrm{H}$
$1.30 E+06$
$4.30 E+05$
$2.50 E+04$
$3.90 E+03$
$6.60 E+07$
$2.20 E+09$

$38 \mathrm{H}$

$43 \mathrm{H}$

2.30E+05 1.70E+05

4.40E+05 3.20E+05

$5.00 E+05 \quad 4.10 E+05$

$1.70 E+03 \quad 1.60 E+03$

4.90E+06 3.20E+06

$2.20 E+09 \quad 1.50 E+09$

$\begin{array}{rr}1 . & 0.04 \\ 1 . & 0.76 \\ 1 . & 0.01 \\ 1 . & 1.16 \\ 1 . & \text { not detect. } \\ 1 . & 0.81 \\ & \\ 5.72 E-04 & 2.76 E-05 \\ 1.59 E-04 & 1.48 E-04 \\ 3.99 E-05 & 2.80 E-07 \\ 1.60 E-06 & 2.28 E-06 \\ 1.80 E-02 & \text { not detect. } \\ 1 . & 1 .\end{array}$

Note: data is from "Composition of Waste Tank Supernate Samples", D.D.Walker/et.al., 7/16/93, WSRC-RP-93-1009.

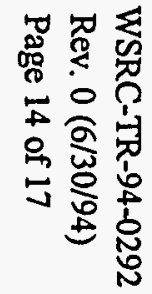


Table 3

Routine Supernate Samples
WSRC-TR-94-0292

Rev. 0 (6/30/94)

Page 15 of 17

\begin{tabular}{|c|c|c|c|c|}
\hline & & $\begin{array}{c}\text { Tc-99 } \\
\text { (Cllgal) }\end{array}$ & $\begin{array}{l}\text { Cs-137 } \\
\text { (CIlgal) }\end{array}$ & $\begin{array}{l}T c-99 / \\
C s-137 \\
(C \cup C) \\
\end{array}$ \\
\hline $\begin{array}{c}N= \\
\min = \\
\operatorname{avg}= \\
\max =\end{array}$ & & $\begin{array}{c}20 \\
8.01 E-07 \\
4.91 E-04 \\
1.96 E-03\end{array}$ & $\begin{array}{c}20 \\
8.01 E-03 \\
2.91 E+\infty \\
1.11 E+01\end{array}$ & $\begin{array}{c}20 \\
1.00 E-04 \\
1.90 E-04 \\
4.18 E-04\end{array}$ \\
\hline $09 / 02 / 82$ & Tank 20 & $3.07 E-05$ & $1.02 E-01$ & $3.00 E=04$ \\
\hline $08 / 01 / 82$ & Tank 20 & $2.39 E-05$ & $1.06 \mathrm{E}-03$ & $2.26 \mathrm{E}-02$ \\
\hline $\begin{array}{l}07 / 13 / 82 \\
11 / 14 / 81\end{array}$ & $\begin{array}{l}\text { Tank 20 } \\
\text { Tank 20 }\end{array}$ & $\begin{array}{l}3.41 E-05 \\
4.09 E-05\end{array}$ & $\begin{array}{l}2.22 E-01 \\
2.90 E-01\end{array}$ & $\begin{array}{l}1.54 E-04 \\
1.41 E-04\end{array}$ \\
\hline $10 / 31 / 81$ & Tank 20 & $1.19 E-05$ & $3.58 E-02$ & 3.33E-04 \\
\hline 10/08/82 & Tank 21 & 1.47E-05 & 9.21E-02 & 1.59E-04 \\
\hline $09 / 23 / 82$ & Tank 21 & 6.14E-05 & 4.09E-01 & $1.50 E-04$ \\
\hline $09 / 21 / 82$ & Tank 21 & 1.23E-04 & 7.16E-01 & 1.71E-04 \\
\hline $06 / 03 / 82$ & Tank 21 & 8.01E-07 & 8.01E-03 & $1.00 E-04$ \\
\hline $05 / 20 / 82$ & Tank 22 & 1.43E-05 & 1.12E-01 & $1.28 E-04$ \\
\hline $08 / 13 / 88$ & Tank 26 & $6.82 E-04$ & $5.46 E+\infty 0$ & 1.25E-04 \\
\hline 07/20188 & Tank 27 & 5.29E-04 & $3.75 E+\infty 0$ & 1.41E-0.4 \\
\hline $07 / 20 / 88$ & Tank 28 & 6.82E-04 & $4.43 E+\infty 0$ & 1.54E-04 \\
\hline $11 / 27 / 88$ & Tank 29 & $1.96 E-03$ & $1.11 E+01$ & 1.77E-04 \\
\hline $\begin{array}{l}11 / 28 / 88 \\
04 / 09 / 88\end{array}$ & $\begin{array}{l}\text { Tank } 30 \\
\text { Tank } 30\end{array}$ & $\begin{array}{l}9.89 E-04 \\
1.30 E-03\end{array}$ & $\begin{array}{l}8.18 E+\infty \\
9.55 E+\infty\end{array}$ & $\begin{array}{l}\text { 1.21E-04 } \\
1.36 E-04\end{array}$ \\
\hline $11 / 28 / 6$ & Tank 32 & 7.33E-04 & $3.75 E+\infty$ & 1.95E-04 \\
\hline $4 / 28 / 8$ & Tank 33 & 7.84E-0. & 1.88 & 4.18E-04 \\
\hline $04 / 29 / 8$ & Tank 34 & 5.29E-04 & $1.88 \mathrm{E}$ & $2.82 E-04$ \\
\hline $11 / 23 / 8$ & Tank 38 & 7.50E-0.4 & $3.75 E+\infty$ & $2.00 \mathrm{E}-04$ \\
\hline $11 / 23 / 88$ & Tank 43 & $5.46 E-04$ & $2.56 \mathrm{E}+\infty 0$ & 2.13E-04 \\
\hline & $\mathrm{k} 50$ & $3.29 E-06$ & $8.92 \mathrm{E}-06$ & $3.68 E-01$ \\
\hline $11 / 24 / 89$ & Ta & $3.43 E-06$ & 8.92E-06 & 3.84E-01 \\
\hline $10 / 11 / 89$ & Tank 50 & $2.72 E-06$ & 8.92E-06 & 3.05E-01 \\
\hline $10 / 11 / 89$ & Tank 50 & $2.72 E-06$ & 8.92E-06 & $3.05 E-01$ \\
\hline $09 / 15 / 89$ & Tank 50 & 3.24E-06 & 8.45E-06 & 3.83E-01 \\
\hline $09 / 15 / 89$ & Tank 50 & $3.24 E-06$ & 8.45E-06 & 3.83E-01 \\
\hline $08 / 18 / 89$ & Tank 50 & 4.69E-06 & 9.39E-06 & 5.00E-01 \\
\hline $08 / 18 / 89$ & Tank 50 & 4.69E-06 & $9.39 E-06$ & $5.00 \mathrm{E}-01$ \\
\hline $08 / 01 / 89$ & Tank 50 & 5.12E-06 & $9.48 E-06$ & $5.40 E-01$ \\
\hline $08 / 01 / 89$ & Tank 50 & 2.11E-06 & $9.39 \mathrm{E}-06$ & $2.25 E-01$ \\
\hline $06 / 23 / 89$ & Tank 50 & $7.60 E-06$ & $9.81 E-06$ & $7.75 E-01$ \\
\hline $06 / 23 / 89$ & Tank 50 & 7.60E-06 & $1.04 E-05$ & 7.33E-01 \\
\hline $03 / 17 / 89$ & Tank 50 & 1.41E-05 & $9.39 E-06$ & $1.50 E+\infty 0$ \\
\hline $03 / 17 / 89$ & Tank 50 & $1.36 E-0.5$ & 8.92E-06 & $1.53 E+00$ \\
\hline $02 / 19 / 89$ & Tank 50 & $2.82 E-06$ & $1.07 E-05$ & 2.62E-01 \\
\hline $02 / 19 / 89$ & Tank 50 & 9.39E-07 & 1. 13E-05 & 8.33E-02 \\
\hline $01 / 30 / 89$ & Tank 50 & 2.11E-06 & $1.29 E-05$ & 1.64E-01 \\
\hline $01 / 30 / 89$ & Tank 50 & 1.88E-06 & 1.30E-05 & 1.45E-01 \\
\hline $12 / 08 / 88$ & Tank 50 & $2.21 \mathrm{E}-06$ & $5.02 E$ & 4.39E-01 \\
\hline $12 / 08 / 88$ & Tank 50 & $2.25 E-06$ & 5.35E-06 & 4.21E-01 \\
\hline $11 / 03 / 88$ & Tank 50 & $1.50 E-05$ & 8.45E-06 & $1.78 E+\infty 0$ \\
\hline $11 / 03 / 88$ & Tank 50 & $1.47 E-05$ & 9.39E-06 & $1.57 E+\infty 0$ \\
\hline & Tank 50 & 1.63E-05 & $9.29 E-06$ & $1.76 E+\infty$ \\
\hline $08 / 30 / 88$ & Tank 50 & 1.56E-05 & 9.29E-06 & $1.68 E+\infty 0$ \\
\hline $07 / 27 / 88$ & Tank 50 & 1.17E-05 & $9.48 E-06$ & $1.24 E+\infty 0$ \\
\hline $07 / 27 / 88$ & Tank 50 & 1.17E-05 & 8.96E-06 & $1.30 \mathrm{E}+\infty$ \\
\hline 06/03/88 & Tank 50 & 1.53E-05 & 8.87E-06 & $1.72 E+00$ \\
\hline $06 / 03 / 88$ & Tank 50 & 1.43E-05 & 1.37E-05 & $1.04 E+\infty 0$ \\
\hline $05 / 03 / 88$ & Tank 50 & $1.92 E-05$ & 7.56E-06 & $2.54 E+00$ \\
\hline $05 / 03 / 88$ & Tank 50 & 1.92E-05 & $7.56 E-06$ & $2.55 E+\infty$ \\
\hline $03 / 29 / 88$ & Tank 50 & $8.78 E-06$ & $7.27 E-06$ & $1.21 E+\infty$ \\
\hline $03 / 29 / 88$ & Tank 50 & 8.92E-06 & $6.38 \mathrm{E}-06$ & $1.40 E+\infty 0$ \\
\hline $02 / 27 / 88$ & Tank 50 & $1.66 \mathrm{E}-05$ & $6.24 E-06$ & $2.66 E+\infty$ \\
\hline $02 / 27 / 88$ & Tank 50 & 1.62E-05 & $6.52 E-06$ & $2.48 E+\infty 0$ \\
\hline $05 / 27 / 86$ & Tank 50 & 2.74E-05 & $5.73 E-06$ & $4.78 E+\infty$ \\
\hline $06 / 27 / 86$ & Tank 50 & $2.94 E-05$ & $6.05 E-06$ & $4.85 \mathrm{E}+\infty$ \\
\hline
\end{tabular}

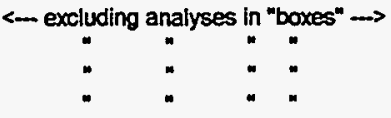
$\mathbf{N}=$
$\min =$
avg $=$
$\max =$

Sr-90 Cs-137 Cs-137 (Cl/gal) (Ciloal) (CIJC)

03/11/71 Tank 1 5.11E-03 2.56E+01 2.00E-04 080470 Tank 1 3.41E-03 1.70E+01 2.00E-04 02/20/69 Tank 1 8.52E-04 2.39E+01 3.57E-05

0823rio Tank 2 3.07E-04 2.22E+01 1.38E-05 02/19169 Tank 2 1.70E-04 1.36E+01 1.25E-05

02/28/69 Tank $5 \quad 1.53 E-03 \quad 3.92 E+01 \quad 3.91 E-05$

02/28/69 Tank $6 \quad 1.19 E-03 \quad 6.82 E+\infty \quad 1.75 E-04$ 03\%7/109 Tank $8 \quad 2.05 E-03 \quad 4.43 E+01 \quad 4.62 E-05$ 01/10/69 Tank $9 \quad 5.11 E-04 \quad 6.82 E+\infty 0 \quad 7.50 E-05$ 0621775 Tank 10 3.41E-06 7.67E-01 4.44E-06

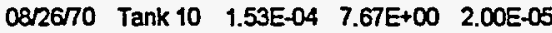
01/04/69 Tank $10 \quad 6.82 \mathrm{E}-05 \quad 1.36 \mathrm{E}+01 \quad 5.00 \mathrm{E}-06$

02/24/77 Tank 13 1.24E-02 7.33E-01 1.70E-02 12/18/68 Tank $13 \quad 3.41 E-05 \quad 1.70 E+\infty \quad 2.00 E-05$

01/02/69 Tank $14 \quad 3.07 E-03 \quad 3.41 E+00 \quad 9.00 E-04$

$12 / 17 \pi 1$ Tank $15 \quad 4.43 E-03 \quad 3.41 E+\infty 0 \quad 1.30 E-03$ $1008 / 71$ Tank 15 5.11E-03 $3.41 \mathrm{E}+\infty 0$ 1.50E-03 12/18/68 Tank $15 \quad 3.58 E-03 \quad 8.52 E+00 \quad 4.20 E-04$

10/19/71 Tank $17 \quad$ 1.69E-05 4.09E-03 4.13E-03 10/13/71 Tank $18 \quad 1.31 E-05 \quad 1.52 E+\infty 0 \quad 8.65 E-06$ 10/13/71 Tank $19 \quad$ 4.94E-06 1.26E+00 3.92E-06 10/13/71 Tank $20 \quad 1.09 E-05 \quad 2.22 E+\infty 0 \quad 4.92 E-06$ 1008/82 Tank $21 \quad$ 6.14E-06 9.21E-02 6.67E-05 05/20/82 Tank $22 \quad$ 1.65E-05 1.12E-01 1.48E-04 1023/71 Tank 22 9.04E-07 2.73E-02 3.31E-05 \begin{tabular}{llllll}
\hline 10/23/71 Tank 23 & $6.14 E-06$ & $5.11 E-05$ & $1.20 E-01$ \\
\hline
\end{tabular} 1023/71 Tank $24 \quad 2.22 E-06 \quad 6.82 E-01 \quad 3.25 E-06$ 0826770 Tank $24 \quad 1.02 \mathrm{E}-04 \quad 1.19 \mathrm{E}+\infty 0 \quad 8.57 \mathrm{E}-05$ 04/09/88 Tank $30 \quad 2.22 E-02 \quad 9.55 E+\infty 0 \quad 2.32 E-03$ 02/24/77 Tank $31 \quad 3.58 E-03 \quad 1.23 E+\infty \quad 2.92 E-03$ 4/28/88 Tank $33 \quad 1.31 E-03 \quad 1.88 E+\infty \quad 7.00 E-04$ 04/29/88 Tank $34 \quad 1.07 E-03 \quad 1.88 E+\infty 0 \quad 5.73 E-04$ 01/11/72 Tank $34 \quad 7.50 E-04 \quad 1.36 E+01 \quad 5.50 E-05$

Note: data is from "Radionuclide Sample Analysis of Waste Tanks 1-51", J.A.Pike, 1/24/94, HLW-HLE-94-0328. 


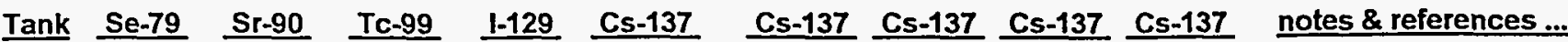

\begin{tabular}{|c|c|c|c|c|c|c|c|c|c|}
\hline \multirow[b]{2}{*}{13} & \multicolumn{5}{|c|}{$\mathrm{mCi} / \mathrm{L}$ of solution } & \multicolumn{4}{|c|}{ isotope ratios, $\mathrm{Ci} / \mathrm{Ci}$} \\
\hline & $4.5 \mathrm{E}-04$ & $9.1 E-03$ & 4.0E-04 & - & $2.5 E+00$ & $1.8 E-04$ & $3.6 \mathrm{E}-03$ & $1.6 E-04$ & $\cdot$ \\
\hline 47 & $6.4 E-05$ & 1.1E-02 & $2.9 \mathrm{E}-04$ & - & $8.6 \mathrm{E}-02$ & 7.4E-04 & 1.3E-01 & $3.4 E-03$ & 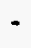 \\
\hline 19 & $1.6 E-04$ & $1.4 \mathrm{E}-01$ & $1.2 \mathrm{E}-02$ & - & $\cdot$ & - & - & - & - \\
\hline 20 & 1.7E-03 & - & $3.2 E-02$ & - & - & - & - & - & - \\
\hline 24 & $1.1 E-02$ & not detect. & 7.7E-02 & - & $4.4 E+00$ & $2.5 E-03$ & not detect. & $1.8 E-02$ & - \\
\hline 24 & $3.2 E-03$ & $6.0 E-03$ & 4.3E-02 & $\cdot$ & $3.5 E+02$ & $9.2 E-06$ & $1.7 E-05$ & $1.2 E-04$ & - \\
\hline 24 & - & - & $9.6 E-02$ & - & $3.5 E-01$ & - & - & 2.7E-01 & - \\
\hline 24 & 2.0E-03 & not detect. & $5.9 \mathrm{E}-02$ & - & $1.9 E+02$ & $1.1 E-05$ & not detect. & $3.2 E-04$ & - \\
\hline & \multicolumn{5}{|c|}{$\mathrm{mCi} / \mathrm{L}$ of salt cake } & & & & \\
\hline$T$ & $3.2 E-02$ & $4.3 E+00$ & 2.5E-02 & - & $1.0 E+03$ & $3.1 E-05$ & $4.2 \mathrm{E}-03$ & $2.4 \mathrm{E}-05$ & - \\
\hline 1 & $2.9 \mathrm{E}-02$ & $3.3 E+00$ & $1.8 \mathrm{E}-01$ & - & $1.0 E+03$ & 2.8E-05 & $3.2 E-03$ & 1.7E-04 & - \\
\hline
\end{tabular}

per J.R.Fowler's DPSTN-3302:

supernate sampled 6/30/81, p 17

concentrated supernate sampled 7/13/81, p 17

dissolved salt soln sampled 8/19/81 (in Tank 18), p 21

dissolved salt solution sampled 8/19/81, p 22-23

dissolved salt solution sampled 8/26/81, p 24-25

dissolved salt solution sampled 10/21/81, p 35

dissolved salt solution sampled 11/25/81, p 47

dissolved salt solution sampled 6/17/82, p 63

\section{per J.R.Fowler's DPSTN-3302:}

1st analysis of dry saltcake sampled 5/21/81, $p 7$

dupl analysis of dry saltcake sampled 5/21/81, p 11

Ci/gal of supernate (based on $400 \mathrm{gm}$ salt /L)

\section{per DPST-84-334:}

PUREX HAW supernate

PUREX LAW supernate

PUREX LAW supernato

PUREX LAW supernate

PUREX LAW supernate

PUREX LAW supernate

PUREX LAW supernate

PUREX LAW supernato

\section{PUREX concentrated supernate}

HM HAW supernate

HM LAW supernate

HM concentrated supernate

PUREX saltcake

PUREX saltcake

PUREX dissolved saltcake

PUREX dissolved saltcake

HM saltcake

HM saltcake

\section{per DPST-84-343:}

fresh supernate (not yet conc by an evapr)

fresh supernate (not yet conc by an evapr)

concentrated supernate

concentratod supernate (as corroctod per ref 12a)

concentrated supernate

saltcake (equiv supern at $400 \mathrm{gm}$ salthiter) 
Chart 1

Cs-137 per Routine Supernate Samples

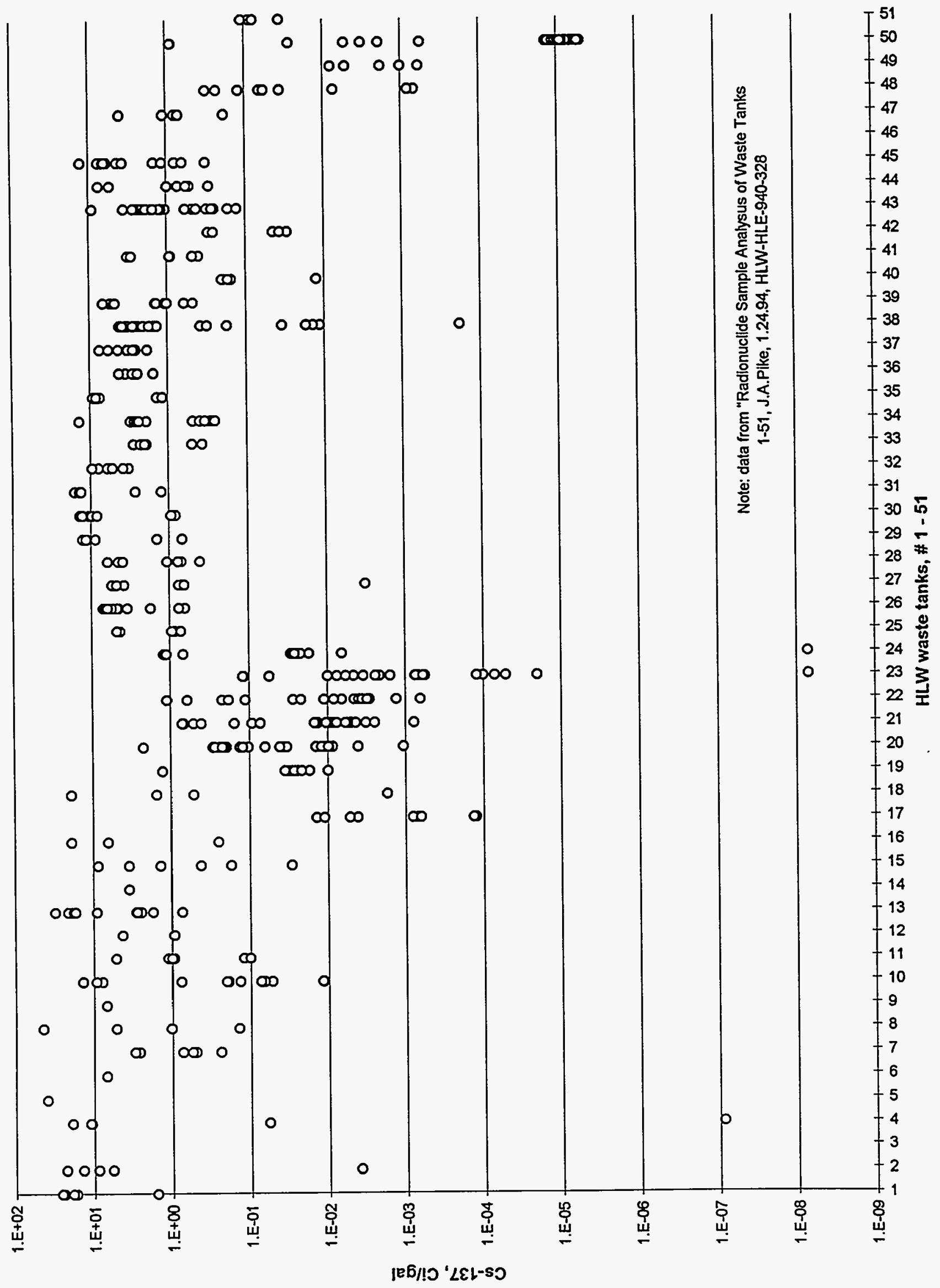

WSRC-TR-94-0292

Rev. 0 (6/30/94)

Page 17 of 17 